\title{
Herpes simplex viruses type 1 and 2 photoinactivated in the presence of methylene blue transform human and mouse cells in vitro
}

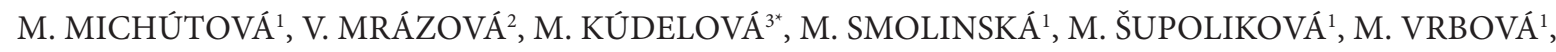 \\ F. GOLAIS ${ }^{*}$
}

\begin{abstract}
${ }^{1}$ Department of Microbiology and Virology, Faculty of Natural Science, Comenius University in Bratislava, Ilkovičova 6, 84215 Bratislava, Slovak Republic; ${ }^{2}$ St Elizabeth Cancer Institute, Bratislava, Slovak Republic; ${ }^{3}$ Department of Molecular Pathogenesis of Viruses, Institute of Virology, Biomedical Research Center Slovak Academy of Sciences, Bratislava, Slovak Republic
\end{abstract}

Received February 21, 2017; revised March 29, 2017; accepted June 26, 2017

\begin{abstract}
Summary. - Three strains of herpes simplex virus, K17 $7^{\text {syn- }}$ and HSZP ${ }^{\text {syn+ }}$ of type 1 (HSV-1) and US ${ }^{\text {syn- of }}$ type 2 (HSV-2), were photoinactivated in the presence of methylene blue and used to infect 3 cell lines, normal human lung tissue cells (MRC-5), mouse epithelial cells (NIH3T3), and human lung carcinoma cells (A549). The virus titer and phenotype of cells were evaluated to compare the characteristics of normal and carcinoma cells infected with non-syncytial (non-syn) and syncytial (syn) strains of herpes simplex viruses. We found that the cells of both normal cell lines infected with photoinactivated K17 $7^{\text {syn- }}$ and US ${ }^{\text {syn- }}$ but not HSZP $^{\text {synt }}$ acquired transformed phenotype accompanied by the presence of virus. Surprisingly, the infection with photoinactivated viruses $\mathrm{K}_{1} 7^{\mathrm{syn}-}$ and US ${ }^{\text {syn- }}$ but not $\mathrm{HSZP}^{\text {syn+ }}$ resulted in the suppression of the transformed phenotype of A549 cells. Using nested PCR, herpesviral DNA was identified in newly transformed cells and cells that lost the transformed phenotype. The effect of putative herpesvirus-related growth factors (HRGF) produced by cells infected with photoinactivated viruses was quantified and compared. Since methylene blue is currently used in phototherapy of herpetic lesions, these results raise the question of whether such therapy is risky to human health.
\end{abstract}

Keywords: herpes simplex viruses; photoinactivation of viruses; methylene blue; putative herpesvirus-related growth factors; transformed phenotype; phototherapy

\section{Introduction}

At present, there is no direct evidence that human alphaherpesviruses herpes simplex virus type 1 (HSV-1) or 2 (HSV-2) may be oncogenic. Although some seroepidemiological and biological studies have pointed to the possible role of HSV-2 in the development of cervical cancer (Nahmias et al., 1974; Goldberg and Gravell, 1976; Rapp and Red, 1976; Thankamani et al., 1985), other attempts have failed to

*Corresponding authors. Dr. F. Golais: E-mail: franz_golais@yahoo. de; phone: +421-2-60296-487; Dr. M. Kúdelová: E-mail: virukude@ savba.sk; phone: +421-2-59302-434.

Abbreviations: $\mathrm{HRGF}=$ putative herpesvirus-related growth factors; HSV $-1,-2=$ herpes simplex virus type 1 and $2 ; \mathrm{MB}=$ methylene blue; MHV-68 = murine gammaherpesvirus 68 ; $\mathrm{NR}=$ neutral red support this idea (Vonka et al., 1984; Lehtinen et al., 2002). Both HSV-1 and HSV-2, however, are still considered to be in relationship to some cancers such as epithelial skin cancer (Ypiranga and de Morales, 2009), squamous cell carcinoma (Metgut et al., 2012; Gupta and Metgud, 2013), oral cancer (Shillitoe and Silverman, 1979; Stele and Shillitoe, 1991), oropharyngeal cancer (Starr et al., 2001), thyroid cancer (Stamatiou et al., 2016), and prostate cancer (Thomas et al., 2011, Yun et al., 2016). Attempts to demonstrate the ability of human alphaherpesviruses to transform cells in vivo failed as their transforming potential is masked by extensive cytopathology and the death of infected cells. The elimination of cell death could be accomplished for example by UV irradiation. UV-irradiated HSV-1 and HSV-2 lost their ability to cause cytopathic effect (CPE) and foci of transformed cells appeared in the culture monolayer (Duff and Rapp, 
1971; Rapp and Duff, 1973). Recently, similar results were obtained by Mrázová et al. (2015) with UV-irradiated murine gammaherpesvirus 68 (MHV-68).

Another approach to eliminate the lytic activity of viruses is photodynamic inactivation, when a virus is treated with photosensitizer such as neutral red (NR) or methylene blue (MB) and exposed to visible light. This treatment results in the destruction of virus infectivity (Yen and Simon, 1978; Schnipper et al., 1980; Bodylak et al., 1983; Costa, 2012). Studies employing the photoinactivation of HSV-1 and HSV-2 in the presence of NR have shown that under conditions, in which virus infectivity is destroyed, the photoinactivated virus can morphologically transform the cells in vitro, similar to UV-irradiated virus (Li et al., 1975, Kucera et al., 1977; Rapp and Kemeny, 1977). All cells transformed by HSV-1 and HSV-2 shared similar properties. They synthetized HSV-specific antigens detected by immunofluorescence, contained virus DNA, were resistant to superinfection with homologous transforming virus, and produced tumors in weanling animals after subcutaneous inoculation. Tumorbearing animals produced neutralizing antibodies against transforming virus (Rapp and Duff, 1973; Rapp and Reed, 1976; Kucera et al., 1977). Similar results were obtained in cells transformed by UV-inactivated MHV-68. Virus DNA and virus antigen could be detected by PCR and immunofluorescence methods; furthermore, the disappearance of actin bundles was observed, indicating that transformed cells might be oncogenic (Mrázová et al., 2015).

In the 1990s, a novel class of compounds resembling growth factors, which cannot be related to any hitherto known cellular products, was found produced by herpesviruses and characterized. These putative HRGF have the ability to transform normal non-transformed cells and to suppress the transformed phenotype when added to transformed cells. Both activities of putative growth factors could be neutralized not only by antisera to the corresponding virus, but also by some monoclonal antibodies directed against viral gB glycoproteins (Golais et al., 1988, 1992a,b; Konvalina et al., 2002; Supoliková et al., 2015). It has been also found that non-syncytial but not syncytial strains of HSV-1 were able to produce these compounds during infection of cells (Golais et al., 1992a,b). To take a position on this, we included into the study HSZP strain of HSV-1, suggested to be associated with the absence of HRGF in some cells. HSZP is a non-pathogenic syncytial strain of HSV-1 forming large polykaryocytes in infected cell cultures due to a syn ${ }^{3}$ mutation in the C-terminal endodomain of glycoprotein B (Rajčáni et al., 1996,1999; Kúdelová et al., 1998). Several important in vitro and molecular studies have shown abolished shutoff function of the HSZP virus due to at least four out of six specific mutations seen in vhs polypeptide encoded by the UL41 gene (Matis and Kúdelová, 2001). In vivo studies have shown that HSZP is poorly reactivable and shows limited neural spread in mice (Kúdelová et al., 1996).

As already mentioned, photoinactivated herpesviruses may transform cells in vitro, thus indicating that they might be oncogenic in vivo. A human clinical therapeutic procedure based on photodynamic inactivation has been developed. This treatment consists of applying a photosensitizing dye to herpetic lesions and then exposing them to visible light. Taking into account previous data, this procedure can represent a potential cancer risk (Bockstahler et al., 1979; Rapp and Li, 1982). NR was one of the first, although not very effective, photosensitizers used for treatment of herpetic lesions (Myers et al., 1975, 1976; Roome et al., 1975). However, satisfactory results have been obtained using MB (Chang et al., 1975; Tardivo et al., 2005, 2012; Marotti et al., 2009, 2010; Sperandio et al., 2009; Ramalho et al., 2015). No transforming ability of any strain of HSV-1 or HSV-2 photoinactivated in the presence of MB has been demonstrated as yet.

The aim of this study was to evaluate the impact of in vitro infection with photoinactivated HSV-1 and HSV-2 of normal non-transformed and transformed cells, respectively, contributing to the clarification of the possible health hazard of the aforementioned treatment of herpetic lesions. Some issues of HSV-1- and HSV-2-associated putative growth factors were also addressed.

\section{Materials and Methods}

Viruses. The HSV-1 K17 strain was obtained from the MRCUniversity of Glasgow Centre for Virus Research, Glasgow (Scotland, UK). This strain has non-syncytial (in this study designed as HSV-1 K17 $7^{\text {syn-}}$ ) plaque morphology (Shubak-Sharpe, 1973). The HSV-1 HSZP strain and the HSV-2 US strain were obtained from the collection of the Department of Molecular Pathogenesis of Viruses, Institute of Virology, Biomedical Research Center, Bratislava (Slovakia). HSZP is a non-pathogenic syncytial (in this study designed as HSV-1 HSZP ${ }^{\text {syn }}$ ) strain of HSV-1 forming large polykaryocytes in infected cells. HSV-2 US has non-syncytial (in this study designed as HSV-2 US ${ }^{\text {syn-}}$ ) plaque morphology.

Cells. The following cells were used: BHK-21 cells (ATCC CCL10) derived from the kidneys of 1-day-old hamsters (Stoker and MacPherson, 1964); MRC-5 (ATCC CCL-171), a human diploid cell culture established from the normal lung tissue of a 14-weekold male fetus (Jacobs et al., 1970); NIH3T3 cells, mouse fibroblasts obtained from Swiss albino mouse embryo tissue (Todaro and Green, 1963); and A549 cells (ATCC CRM-CCL-185), a human lung carcinoma cell line originating from an explant culture of carcinomatous lung tissue from a 58-year-old Caucasian male (Giard et al., 1973). The cells were cultivated in Dulbecco's Modified Eagle Medium (DMEM) supplemented with 7\% fetal bovine serum (FBS), 1\% L-glutamine, and 1\% Penicillin/Streptomycin/ 
Amphotericin B (PSA) and incubated at $37^{\circ} \mathrm{C}$ in a humidified $5 \%$ $\mathrm{CO}_{2}$ atmosphere.

Photodynamic inactivation. Methylene blue (Loba Feinchemie $\mathrm{GmBH}$, Fischamend, Austria) diluted in phosphate-buffered saline was added to $1 \mathrm{ml}$ of virus suspension of HSV-1 K17 ${ }^{\text {syn- }}$, HSV-1 $\mathrm{HSZP}^{\text {syn }}$, and HSV-2 US ${ }^{\text {syn- }}$ containing $1 \times 10^{6} \mathrm{PFU}$ in $6 \mathrm{~cm}$ plastic Petri dishes to a final concentration of $10^{3} \mathrm{mmol} / \mathrm{l}$. The virus suspension was then exposed to light-emitting diodes (LED) at a distance of $5 \mathrm{~cm}$ at $37^{\circ} \mathrm{C}$. A monochromatic LED red light system (homemade device, $\lambda_{\max }=650 \mathrm{~nm}, 16.7 \mathrm{Wm}^{-2}$ ) was used for the experiments. The emission spectrum of the light system was measured with an optical fiber high resolution Red Tide USB-650 fiber optic spectrometer (Ocean Optics, Dunedin, FL, USA). Virus suspension samples taken at intervals $0,30,60,90$, and $120 \mathrm{~s}$ after exposure to visible light were used to infect BHK-21 cells and the virus titer of each individual sample was evaluated. Appropriate photoinactivated samples of viruses were diluted 10 and 100 times and then used to infect triplicates of monolayers of MRC-5, NIH3T3, and A549 cells grown in 24-well plates. Infected cells were observed daily for the appearance of morphological changes. Virus suspensions added to the cells containing the same MB concentration but not exposed to visible light (kept in the dark) and the cells infected with the same dose of non-photoinactivated virus served as negative and positive controls, respectively.

Titration of viruses by plaque assay. Ten-fold dilutions of virus samples in the amount of $0.1 \mathrm{ml}$ were inoculated onto monolayers of BHK-21 cells in the 24-well plates in triplicate. After an incubation period of $60 \mathrm{~min}$ to allow the virus to adsorb to the cells, the monolayers were overlaid with a nutrient medium containing $0.5 \%$ methylcellulose that prevented virus release from the infected cells so that only cell-to-cell spread occurred. After $72 \mathrm{~h}$, the medium containing methylcellulose was removed and the cells were fixed with $4 \%$ formalin and stained with carbolfuchsin. The plaques were counted and the virus titers were expressed as PFU/ml. Data were expressed as mean \pm SD obtained from triplicates.

Morphological and cytological examination of cells. The cells cultivated in 6-cm plastic Petri dishes were fixed with 50\% methanol for $10 \mathrm{~min}$, then $10 \mathrm{~min}$ with $100 \%$ methanol, and stained using the Giemsa-Romanowski method.

Titration of HRGF. To evaluate the transforming activity of HRGF, 10 -fold dilutions (from $10^{0}$ to $10^{8}$ ) of media from cells infected with photoinactivated viruses were added to NIH3T3 or MRC-5 cells grown in 96-well microplates in quadruplicates. The same media samples were added to carcinoma A549 cells to evaluate the transformed phenotype-suppressing activity of HRGF. The limiting dilution of the sample that induced the corresponding activity in $50 \%$ of the cells was considered as 1 HRGF unit. The titer of HRGF (as U/ml) of each sample was calculated taking into account the dilution of the media used. Data were expressed as mean \pm SD obtained from quadruplicates.

Polymerase chain reaction. To detect each strain of HSV-1 or HSV-2 in the examined samples, we used the nested PCR assay targeting the gp061 gene common sequence of both types (in the virus genome from 93,113 to 94,579 nt) encoding the binding protein (GeneBank NC_001806.2). DNA of HSV-1 BAC, HSV-1 K17, and HSV-1 HSZP were purified as previously described and used as a positive control (Kúdelová et al., 1996). DNA from uninfected cells and the PCR mixture without the template were used as negative controls. The sequences of the outer and nested PCR primers (5'-GTGGTCGTCGACGATTGCAGCAT-3' and 5'-GGGAGT GACCCGCGTGGTCGA-3'; 5'-CGACGCGTACCGGTC CGATG-3' and 5'-TGGTGCACGAACAGCGTGGTG-3') amplified 377- and 311-bp-long products, respectively. The primers were synthesized by Microsynth (Balgach, Switzerland). The PCR mixture contained $50 \mathrm{mmol} / \mathrm{l} \mathrm{KCl}, 10 \mathrm{mmol} / \mathrm{l}$ Tris- $\mathrm{HCl}$ (pH 8.5), 0.1\% Triton $\mathrm{X}-100,1.5 \mathrm{mmol} / 1 \mathrm{MgCl}_{2}, 0.3 \mathrm{mmol} / \mathrm{l}$ nucleotides, $0.3 \mathrm{mmol}$ of each primer, $1 \mathrm{U}$ of GoTaq polymerase (Promega, Madison, WI, USA), and the template. The PCR procedure was performed in a $25-\mu$ l total volume with $40 \mathrm{cycles}$ of $94^{\circ} \mathrm{C}$ for $30 \mathrm{~s}, 57^{\circ} \mathrm{C}$ for $30 \mathrm{~s}$, and $72^{\circ} \mathrm{C}$ for $45 \mathrm{~s}$, followed by an extension in a thermal Labcycler (SensoQuest, Göttingen, Germany) at $72^{\circ} \mathrm{C}$ for $5 \mathrm{~min}$. For the second (nested) round, $1 \mu \mathrm{l}$ of the first-round PCR was used as a template under identical conditions, except 35 cycles were used.

\section{Results and Discussion}

To evaluate the effect of photodynamic inactivation on HSV-1 K17 ${ }^{\text {syn- }}$, HSV-1 HSZP ${ }^{\text {syn }+}$, and HSV-2 US ${ }^{\text {syn- }}$, we exposed virus samples of titer approximately $1 \times 10^{6} \mathrm{PFU} / \mathrm{ml}$ to visible light at various time intervals (from 30 to $120 \mathrm{~s}$ ) in the presence of $\mathrm{MB}$. Photoinactivated viruses were then diluted 10 and 100 times and used to infect 24-h-old monolayers of NIH-3T3, MRC-5, and A549 cells. Untreated viruses diluted in the same manner served as negative controls. After 3 days of culture, the titer in the culture media of photoinactivated viruses was evaluated and compared to the controls. We found that the titer of all photoinactivated viruses continuously decreased with increasing light exposure time. As shown in Fig. 1, exposure of $30 \mathrm{~s}$ to visible light in the presence of $\mathrm{MB}$ caused about $30 \%$ decrease of infectivity in all viruses, while the strongest effect on HSV-2 US ${ }^{\text {syn- }}$ could be observed. Furthermore, the infectivity of all viruses was around $50 \%$ after $120 \mathrm{~s}$ of exposure.

Following 7 days of culture of NIH3T3 and MRC-5 infected with photoinactivated HSV-1 K17 ${ }^{\text {syn- }}$, HSV-1 HSZP ${ }^{\text {syn }}$, or HSV-2 US ${ }^{\text {syn- }}$, most of the cells of both cell lines showed incomplete CPE (about 70-90\%), whereas cells infected with untreated viruses were destroyed by a total CPE within 3 days. After 7 days of culture, a relatively small portion of cells of both cell lines infected with any of the photoinactivated HSV-1 K17 $7^{\text {syn- }}$ and HSV-2 US ${ }^{\text {syn- }}$ remained undestroyed by virus infection but acquired altered morphology resembling transformation with a multilayered "criss-cross" pattern of growth. Moreover, cells could be subsequently passaged without the loss of transformed phenotype. We found that NIH3T3 


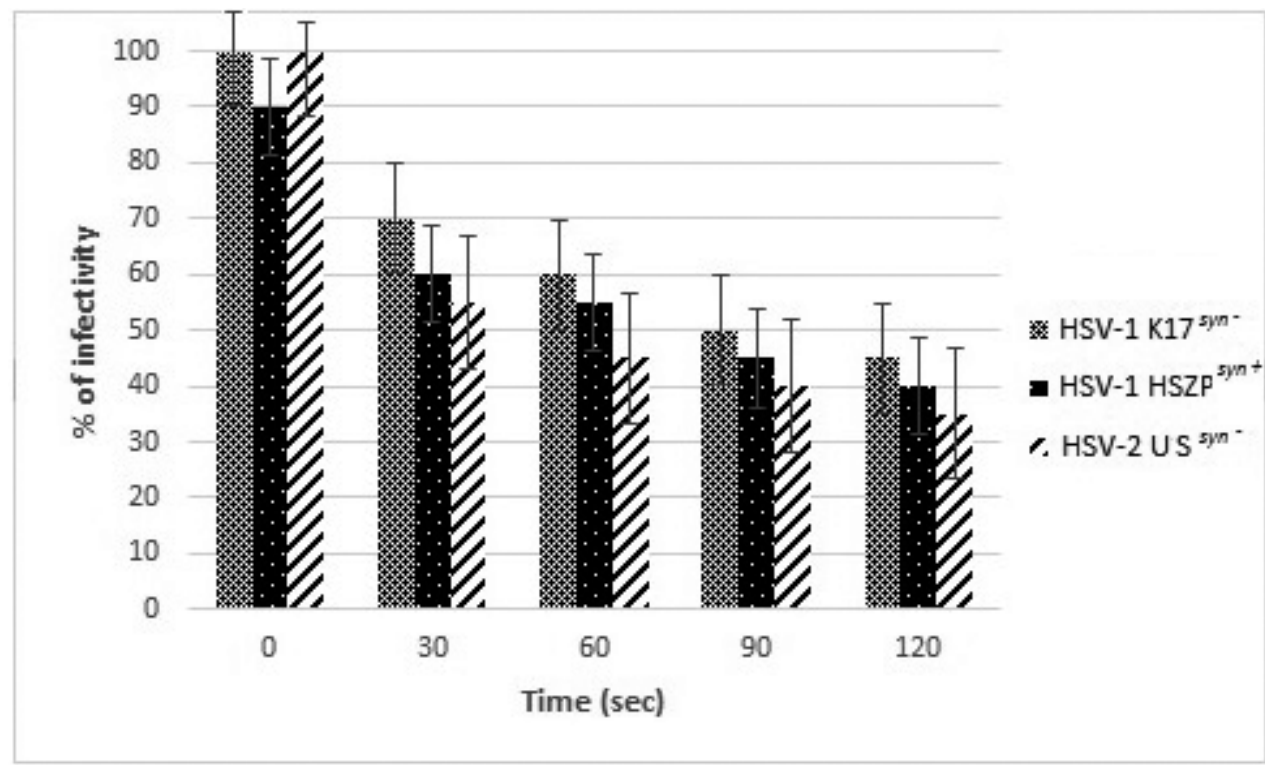

Fig. 1

Reduction of infectivity of HSV-1 K17syn-, HSV-1 HSZP ${ }^{\text {synt }}$, and HSV-2 US ${ }^{\text {syn }}$ - exposed to visible light for 30-120 s Untreated viruses served as negative controls. Data are expressed as mean \pm SD obtained from triplicates.

(a)

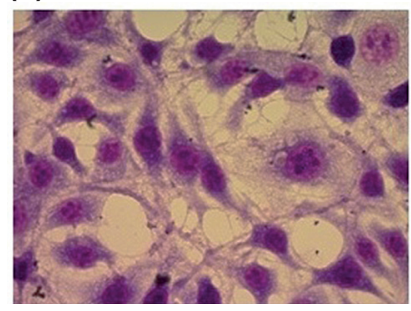

(c)

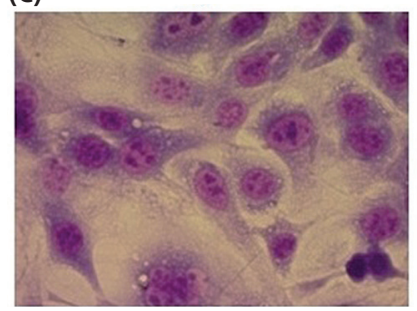

(b)

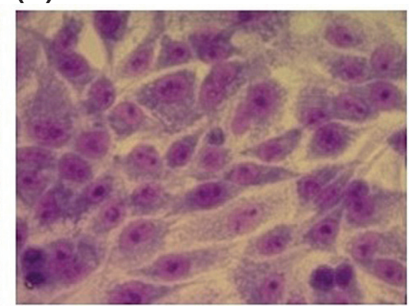

(d)

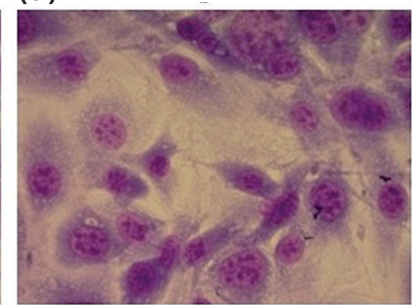

Fig. 2

Changes in NIH3T3 cells phenotype caused by infection with photoinactivated HSV-1 K1 $7^{\text {syn- }}$ (a and b) and HSV-1 $\mathrm{HSZP}^{\mathrm{syn}+}(\mathrm{c})$

(a) and (b) cells after the fifth and tenth passage; (c) cells after the fifth passage; (d) uninfected cells (negative control); magnification 50x.

cells at fifth and tenth passage still displayed the transformed phenotype caused by the photoinactivated HSV-1 K17 ${ }^{\text {syn- }}$

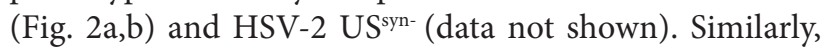

(a)

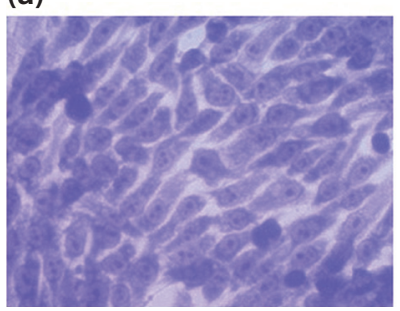

(b)

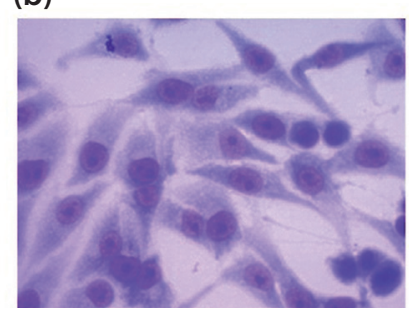

Fig. 3

Changes in MRC- 5 cells phenotype caused by infection with photoinactivated HSV-2 US syn $_{\text {sn }}$

(a) cells after the fifth passage; (b) uninfected cells (negative control). Magnification 50x.

MRC-5 cells displayed the transformed phenotype caused by the photoinactivated HSV-1 K17 $7^{\text {syn- }}$ (data not shown) and HSV-2 US syn- (Fig. 3a). We found that both non-syn herpes simplex viruses of both types used in this study induced stable transformed phenotype in MRC-5 as well as NIH3T3 cells. On the other hand, the infection with photoinactivated syncytial HSV-1 HSZP ${ }^{\text {syn }}$ failed to induce such transformation and the phenotype of NIH3T3 (Fig. 2c) and MRC-5 cells (data not shown) remained the same as that of the cells infected with untreated virus or uninfected cells (Figs. $2 \mathrm{~d}$ and $3 \mathrm{~b}$ ).

In the following experiments, we investigated virus presence in both of cell lines transformed by photoinactivated 
(a)

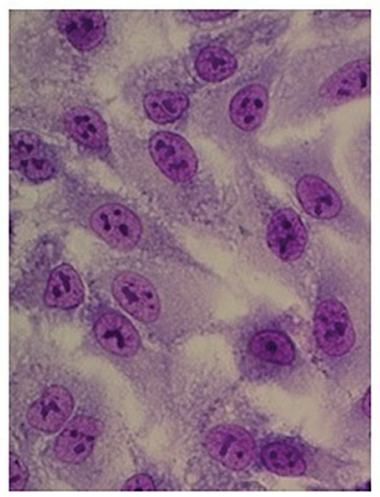

(b)

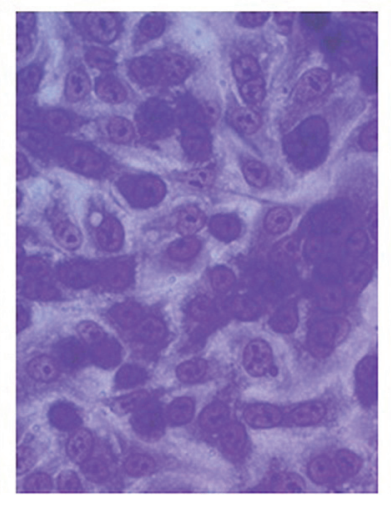

(c)

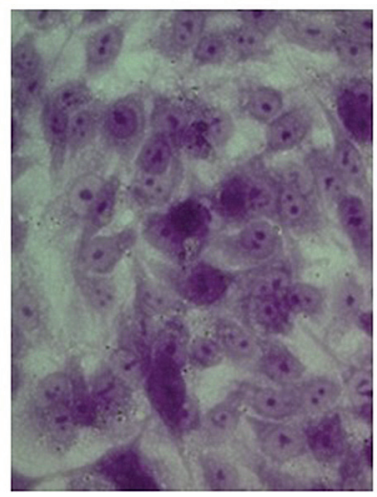

Fig. 4

Changes in carcinoma cells A549 phenotype caused by infection with photoinactivated HSV-1 K17 ${ }^{\text {syn }}-\left(\right.$ a) and HSV-1 HSZP ${ }^{\text {syn }}$ (b)

(a) and (b) cells after the fifth and sixth passage; (c) uninfected cells (negative control). Magnification 50x.

herpes simplex viruses by nested PCR method. Despite of the different effect observed on cells after infection with photoinactivated non-syn (HSV-1 K17 $7^{\text {syn- }}$ and HSV-2 US ${ }^{\text {syn-}}$ ) and

(a)

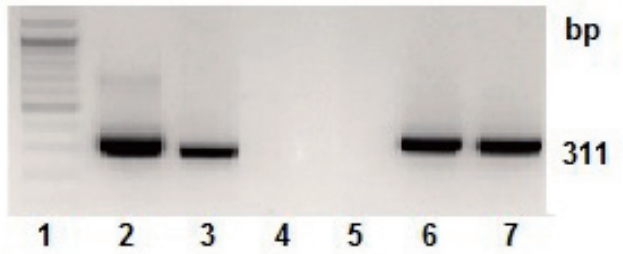

(b)

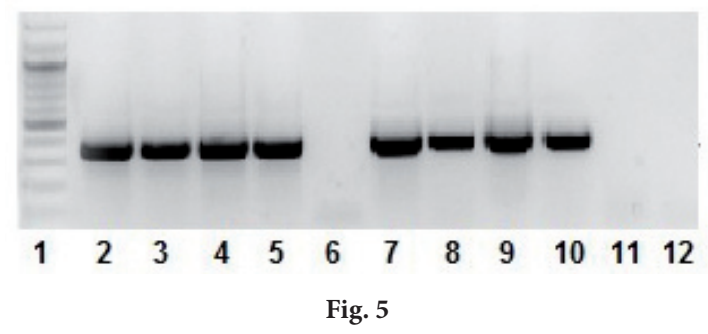

PCR detection of HSV-1 viruses in MRC-5 cells transformed via infection with photoinactivated virus strain $\mathrm{K} 7^{\mathrm{syn}}$ - or $\mathrm{HSZP}^{\mathrm{syn}+}$ (a) and A549 cells that lose transformed phenotype after infection with inactivated virus strain $\mathrm{K}^{\text {syn }}$ - or $\mathrm{HSZP}^{\text {synt }}$ (b)

(a) Lanes 1: 100 bp Plus Ladder (Fermentas); 2 and 3: nested PCR with HSV-1 BAC DNA and 1-step PCR with nested primers and HSV-1 BAC DNA (positive controls); 4: nested PCR without template (negative control); 5: uninfected cells (negative control); 6 and 7: MRC-5 cells infected with photoinactivated $\mathrm{K}^{\mathrm{syn}}$ - and HSZP ${ }^{\mathrm{syn}+}$ (eighth passage). (b) Lanes 1: $100 \mathrm{bp}$ Plus Ladder (Fermentas); 2-3 and 4-5: A549 cells infected with photoinactivated $\mathrm{HSZP}^{\mathrm{syn}+}$ and $\mathrm{K} 7^{\mathrm{syn}-}$ diluted 20 times (lanes 2 and 4 ) and 100 times (lanes 3 and 5); 6: uninfected cells (negative control); 7 and 8: nested PCR with DNA of HSZP and K17 (positive controls); 9 and 10: 1-step PCR with nested primers and DNA of HSZP and K17 (positive controls); 11 and 12: nested PCR without template and 1-step PCR with nested primers without template (negative controls). syn (HSV-1 HSZP ${ }^{\text {syn+ }}$ ) strains, we identified the presence of viral DNA in MRC-5 cells (Fig. 5a) and NIH3T3 cells (data not shown), respectively.

Next, in experiments on carcinoma A549 cells infected with photoinactivated viruses, we observed an opposite effect found for normal cells: a change of transformed phenotype into phenotype resembling the phenotype of normal non-transformed cells. The cells infected with HSV-1 K17 ${ }^{\text {syn- }}$ (Fig. 4a) and HSV-2 $\mathrm{US}^{\text {syn- }}$ (data not shown) retained a normal, non-transformed phenotype after at least 5 following passages. On the other hand, photoinactivated HSV-1 HSZP ${ }^{\text {syn+ }}$, unlike non-syn herpes simplex viruses, failed to induce such a change in the transformed phenotype of A549 cells, which remained unchanged after at least 6 following passages (Fig. 4b). The investigation by molecular methods of A549 cell lines, which after infection with photoinactivated viruses lost transformed phenotype or remained transformed, has shown the presence of DNA of HSV-1 K17 $7^{\text {syn- }}$ and HSV-1 HSZP ${ }^{\text {syn+ }}$ in relevant cells (Fig. 5b)

The fact that photoinactivated syncytial HSV-1 HSZP ${ }^{\text {syn+ }}$ did not induce the morphological changes either in nontransformed NIH3T3 and MRC-5 cells or transformed A549 cells suggest that cells of all these cell lines infected with this virus did not produce compounds resembling growth factors, HRGF, previously shown in cells transformed by some herpesviruses. We found that photoinactivated HSZP is not capable of transforming non-transformed cells and suppressing the transformed phenotype of transformed cells, what is consistent with previous finding that syncytial strains of HSV-1 failed to produce HRGF (Golais et al., 1992a,b; Konvalina et al., 2002). However, this finding is very interesting and needs further studies.

In this study, we demonstrated the acquisition of the transformed phenotype by NIH3T3 and MRC-5 cells as well as the change of the transformed phenotype of A549 cells 


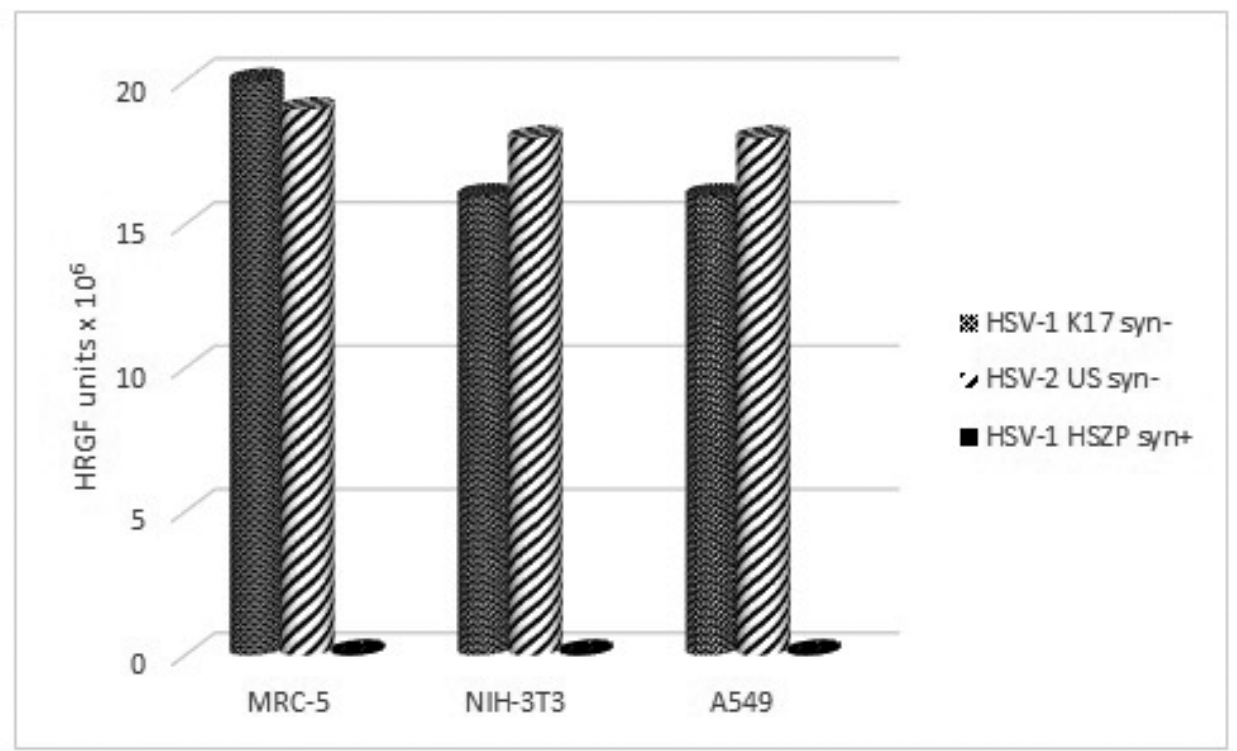

Fig. 6

Titration of putative HRGF produced by MRC-5, NIH3T3, and A549 cells infected with photoinactivated HSV-1 K17 ${ }^{\text {syn }}-$, HSV-1 HSZP ${ }^{\text {syn+ }}$, and

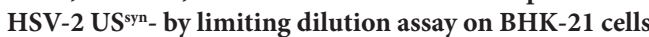

Data expressed as mean \pm SD obtained from quadruplicates ranged from 0.004 to 0.006 .

towards the normal one following infection with photoinactivated non-syncytial herpes simplex viruses HSV-1 K17 synand HSV-2 US ${ }^{\text {syn- }}$. Similar changes of phenotype in normal and transformed cells were recently described for NIH3T3 and HeLa cells infected with UV-irradiated MHV-68 and suggested to be related to putative growth factor MHGF-68 (Mrázová et al., 2015; Šupolíková et al. 2015).

Finally, we compared the production of virus-related growth factors by all cell phenotypes involved. As described in Material and Methods, we quantified the effect of HRGF induced in NIH3T3, MRC-5, and A549 cells by infection with all 3 photoinactivated viruses. Data obtained confirmed that HRFG displayed the strongest effect on the phenotype of NIH3T3 cells infected with photoinactivated non-syncytial strains of HSV-1 and HSV-2. However, no effect of photoinactivated HSV-1 HSZP ${ }^{\text {syn+ }}$ on the phenotype of any cell line was observed (Fig. 6).

Results suggest that the non-syncytial phenotype of herpes simplex virus strains is required for the production of HRGF, which plays an important role in the change of the phenotype of virus-infected cells. It is interesting that the effect of HRGF induced by infection of normal mouse NIH3T3 cells, but also human carcinoma A549 cells, with non-syncytial HSV-2 is stronger than that caused by nonsyncytial HSV-1. This work represents the first study on the absence of effects of photoinactivated HSV-1 HSZP ${ }^{\text {syn+ }}$ on normal as well as transformed cells what is most likely related to the absence of putative growth factors.
As follows from this study, the infection of non-transformed cells with HSV-1 or HSV-2 photoinactivated in the presence of $\mathrm{MB}$ may result in their transformation, which might render this method hazardous. The aim of this work was not to doubt the success of the phototherapy on herpetic lesions. The data gained here pose the question of whether the virus is capable of transforming the cells in vivo and could also be oncogenic in an organism. Nevertheless, the development of modern photodynamic therapy procedures as well as the use of suitable photosensitizers could minimize or remove the possible side effects of this treatment, as suggested by Wainwright (2003).

Acknowledgements. This work was supported by grant \#APVV0621-12 of the Slovak Research and Development Agency and grant VEGA\#2/0087/17. The authors appreciate the HSV-1 BAC kindly provided by Prof. Ulrich H. Koszinowski.

\section{References}

Bockstahler LE, Coohill TP, Hellman KB, Lytle CD, Roberts JE (1979): Photodynamic therapy for herpes simplex. A critical Review. Pharmacol. Ther. 4, 473-499. https:// doi.org/10.1016/0163-7258(79)90144-X

Bodylak JA, Scherba G, Gustafson DP (1983): Photodynamic inactivation of pseudorabiesvirus with methylene blue dye, light and electricity. J. Clin. Microbiol. 17, 374-376.

Costa L, Faustino MAF, Neves MGPMS, Cunha A, Almeida A (2012): Photodynamicinactivation of mammalian vi- 
ruses and bacteriophages. Viruses 4, 1034-1074. https:// doi.org/10.3390/v4071034

Duff R, Rapp F (1971): Properties of hamster embryo fibroblasts transformed in vitro after exposure to ultraviolet-irradiated herpes simplex virus type 2. J. Virol. 8, 469-477.

Giard DJ, Aaronson SA, Todaro GJ, Arnstein P, Kersey JH, Dosik H, Parks WP (1973): In vitro cultivation of human tumors: establishment of cell lines derived from series of solidtumors. J. Natl. Canc. Inst. 51, 1417-1423. https:// doi.org/10.1093/jnci/51.5.1417

Golais F, Koštál M, Csabayová M, Leško J (1992b): The glycoprotein B gene and its syn 3 locus of herpes simplex virus type 1 are involved in the synthesis of virus-associated growth factor (HSGF-1). Acta Virol. 36, 516-523.

Golais F, Sabó A, Bačíková D (1988): Transforming activity of crude extract of pseudorabiesvirus transformed cells. Acta Virol. 32, 83-85.

Golais F, Csabayová M, Leško J, Bystrická M, Sabó A (1992a): Herpes simplex virus type 2 and pseudorabies virus associated growth factors and their role in the latency in vitro. Acta Virol. 36, 505-515.

Goldberg RJ, Gravell M (1976): A search for herpes simplex virus type 2 markers incervical carcinoma. Cancer Res. 36, 795-799.

Gupta K, Metgud R (2013): Evidence suggesting involvement of viruses in oral squamous cell carcinoma. Pathol. Res. Internat. 2013, e17. https://doi.org/10.1155/2013/642496

Chang TW, Fumara N, Weinstein L (1975): Genital herpes: Treatment with methylene blue and light exposure. Int. J. Dermatol. 14, 69-71. https://doi.org/10.1111/j.13654362.1975.tb00084.x

Jacobs JP, Jones CM, Baille JP (1970): Characteristics of human diploid cells designated MRC5. Nature 227, 168-170. https://doi.org/10.1038/227168a0

Konvalina I, Gašperík J, Golais F (2002): A novel class of growth factors related to herpesviruses. Acta vet. Brno 71, 29-36. https://doi.org/10.2754/avb200271010029

Kucera LS, Gudson JP, Edwards I, Herbst G (1977): Oncogenic transformation of rat embryo fibroblasts with photoinactivated herpes simplex virus: Rapid in vitro cloning of transformed cells. J. Gen. Virol. 35, 473-485. https://doi. org/10.1099/0022-1317-35-3-473

Kúdelová M, Dragúň M, Košovský J, Matis J, Rajčáni J (1996): Determination of the target sequence of poorly reactivable strain HSZP of Herpes simplex virus type 1 by polymerase chain reaction. Acta Virol. 40, 15-21.

Kúdelová M, Vojvodová A, Rajčáni J (1998): The syn strains HSZP and ANGpath of herpes simplex virus type 1 do not show mutations in the regions of UL 53 gene relevant to syncytium formation. Acta Virol. 42, 41-45.

Lehtinen M, Koskela P, Jellum E et al. (2002): Herpes simplex virus and risk of cervical cancer: A longitudinal, nested casecontrol study in the nordic countries. Am. J. Epidemiol. 156, 687-692. https://doi.org/10.1093/aje/kwf098

Li JL, Jerkofsky MA, Rapp F (1975): Demanstration of oncogenic potential of mammalian cells transformed by DNA containing viruses following photodynamic inactivation.
Int. J. Cancer. 15, 190-202. https://doi.org/10.1002/ ijc. 2910150204

Marotti J, Aranha ACC, De Paula Eduardo C, Ribeiro MS (2009): Photodynamic therapy can be effective as a treatment for herpes simplex labialis. Photomed. Laser Surg. 27, 357-363. https://doi.org/10.1089/pho.2008.2268

Marotti J, Sperandio FF, Fregnani ER, Aranha ACC, Moreira de Freitas P, Eduardo CdeP (2010): High-intensity laser and photodynamic therapy as a treatment for recurrent herpes labialis. Photomed. Laser Surg. 28, 439-444. https://doi. org/10.1089/pho.2009.2522

Matis J, Kúdelová M (2001): Early shutoff of host protein synthesis in Herpes simplex virus $1 / \mathrm{HSV} 1 /$ infected cells. Acta Virol. 45, 269-277.

Metgud R, Astekar M, Verma M, Sharma A (2012): Role of viruses in oral squamous cell carcinoma. Oncol. Rev. 6, e21. https://doi.org/10.4081/oncol.2012.e21

Mrázová V, Betáková T, Kúdelová M, Šupolíková M, Lachová V, Lapuníková B, Golais F (2015): Murine gammaherpesvirus (MHV-68) transforms cultured cells in vitro. Intervirology 58, 69-72. https://doi.org/10.1159/000370071

Myers MG, Oxman MN, Clark JF, Arndt KA (1975): Failure of neutral-red photodynamicinactivation in recurrent herpes simplex virus infections. New Engl. J. Med. 293, 945-949. https://doi.org/10.1056/NEJM197511062931901

Myers MG, Oxman MN, Clark JF, Arndt KA (1976): Photodynamic inactivation in recurrent infectionwith herpes simplex virus. J. Infect. Dis. 133, 145-150. https://doi.org/10.1093/ infdis/133.Supplement 2.A145

Nahmias AJ, Naub ZM, Josey WE (1974): Epidemiological studies relating genital herpetic infection to cervical carcinoma. Cancer Res. 34, 1111-1117.

Rajčáni J, Vojvodová A, Matis J, Kúdelová M, Dragúňová J, Krivjanská M, Zelník V (1996): The syn3 HSZP of Herpes simplex virus type 1 (HSV-1) is not pathogenic for mice and shows limited neural spread. Virus Res. 43, 33-44. https://doi.org/10.1016/0168-1702(96)01318-4

Rajčáni J, Kúdelová M, Oravcová I, Vojvodová A, Košovský J, Matis J (1999): Characterization of strain HSZP of herpes simplex virus type 1 (HSV-1). Folia Microbiol. 44, 713-719. https://doi.org/10.1007/BF02825668

Ramalho KM, Rocha RG, Aranha ACC, Cunha SRB, Simoes A, Campos L, Eduardo CP (2015): Treatment of herpes simplex labialis in macule and vesicle phases with photodynamictherapy. Report of two cases. Photodiagn. Photodyn. 12, 321-323. https://doi.org/10.1016/j. pdpdt.2015.02.005

Rapp F, Duff R (1973): Transformation of hamster embryofibroblasts by herpes simplex virus type 1 and type 2 . Cancer Res. 33, 1527-1534.

Rapp F, Kemeny BA (1977): Oncogenic potential of herpes simplex virus in mammalian cells following photodynamic inactivation. Photochem. Photobiol. 25, 335-337. https://doi. org/10.1111/j.1751-1097.1977.tb07349.x

Rapp F, Li JLH (1982): Transforming activity of viruses after dyelight inactivation. The Science of Photomedicine, 571594. https://doi.org/10.1007/978-1-4684-8312-3 21 
Rapp F, Reed C (1976): Experimental evidence for the oncogenic potential of herpes simplex virus. Cancer Res. 36, 800-806.

Roome AP, Tinkler AE, Hilton AE, Montefiore DG, Waller D (1975): Neutral red with photoinactivation in the treatment of herpes genitalis. Brit. J. Vener. Dis. 51, 130-133. https://doi.org/10.1136/sti.51.2.130

Shillitoe EJ, Silverman S (1979): Oral cancer and herpes simplex virus-a review. Oral Surg.Oral Med. Oral. Pathol. 48, 216224. https://doi.org/10.1016/0030-4220(79)90006-9

Schnipper LE, Lewin AH, Schwartz M, Crumpacker CS (1980): Mechanism of photodynamicinactivation of herpes simplex viruses: comparison betwen methylene blue, light, plus electricity and hematoporphyrin plus light. J. Clin. Invest. 65, 432-438. https://doi.org/10.1172/JCI109686

Sperandio FF, Marotti J, Aranha ACC, Eduardo C de P (2009): Photodynamic therapy for thetreatment of recurrent herpes labialis: Preliminary results. Gen. Dent. 57, 415-419.

Stamatiou DP, Derdas SP, Zoras OI, Spandidos DA (2016): Herpes and polyoma viruses in thyroid cancer (Review). Oncol. Letters 11, 1635-1644.

Starr JR, Daling JR, Dawn Fitzgibbons E, Madeleine MM, Ashley R, Galloway DA, Schwartz SM (2001): Serologic evidence of herpes simplexinfection and oropharyngeal cancer risk. Cancer Res. 61, 8459-8464.

Stele C, Shillitoe EJ (1991): Viruses and oral cancer. Crit Rev Oral Biol M. 2, 153-175. https://doi.org/10.1177/104544119 10020020201

Stoker M, MacPherson I (1964): Syrian hamster fibroblast cell line BHK21 and its derivatives. Nature 203, 1355-1357. https://doi.org/10.1038/2031355a0

Subak-Sharpe JH (1973): The genetics of herpesviruses. CancerRes. 33, 1385-1392.

Šupoliková M, Vojs Staňová A, Kúdelová M, Marák J, Zelník V, Golais F (2015): Cells transformed by murine herpesvirus 68 (MHV-68) release compounds with transforming and transformed phenotype supressing activity resembling growth factors. Acta Virol. 59, 418-422. https://doi. org/10.4149/av $2015 \quad 04 \quad 418$

Tardivo JP, Del Giglio A, Santos de Oliveira C, Couto Junqueira H, Batista Tada A, Severino D, Terchiello R de F, Baptista MS (2005): Methylene blue in photodynamic therapy: Frombasic mechanisms to clinical applications. Photo- diagn. Photodyn. 2, 175-191. https://doi.org/10.1016/ S1572-1000(05)00097-9

Tardivo JP, Wainwright M, Baptista MS (2012): Local clinical phototreatment of herpes infection in Sao Paulo. Photodiagn. Photodyn. 9, 118-121. https://doi.org/10.1016/j. pdpdt.2012.01.002

Thankamani V, Vasudevan DM, Kumari TV (1985): Detection of herpes simplex virus type 2antigen(s) in biopsies from carcinoma of the uterine cervix. J. Exp Path. 2, 123-133.

Thomas F, Elguero E, Brodeur J, Brodeur J, Le Golf J, Misse D (2011): Herpes simplex virustype 2 and cancer: A medical geography approach. Infect. Genet. Evol. 11, 1239-1242. https://doi.org/10.1016/j.meegid.2011.04.009

Todaro GJ, Gren H (1963): Quantitative studies of the growth of mouse embryo cells in culture and their development into established lines. J. Cell. Biol. 17, 299-313. https:// doi.org/10.1083/jcb.17.2.299

Kumari TV, Vosundevan DM, Ankathil R, Ramani P, Vijayakumar Y (1987): Demonstration of HSV-1 antigen in patients with oral cancer by immunofluorescence andimmunoperoxidase techniques. J. Exp. Pathol. 3, 75-86.

Vonka V, Kanaka J, Hirsch I, Závadová H, Krčmář M, Suchánková A, Řezácová D, Brouček J, Press M, Domorázková E, Svoboda B, Havránková A, Jelinek J (1984): Prospective studies on the relationship between cervical neoplasia and herpes simplex type- 2 virus. II. Herpes simplex type 2 antibody presence in serataken at enrollment. Int. J. Cancer. 33, 61-66. https://doi.org/10.1002/ijc.2910330111

Wainwright M (2003): Local treatment of viral disease using photodynamic therapy. Int. J. Antimicrob. Ag. 21, 510-520. https://doi.org/10.1016/S0924-8579(03)00035-9

Yen GSL, Simon EH (1978): Photosensitization of herpes simplex virus type 1 with neutral red. J. Gen. Virol. 41, 273-281. https://doi.org/10.1099/0022-1317-41-2-273

Ypiranga S, de Moraes AM (2009): Prevalence of human herpes virus type 1 in epithelial skincancer. Ann. Bras. Dermatol. 84, 137-142. https://doi.org/10.1590/S0365$\underline{05962009000200006}$

Yun SJ, Jeong P, Kang HW, Shinn HK et al. (2016): Increased expression of herpes virus-encoded hsv1 miR-H18 and hsv2 miR-H9-58 in cancer containing prostate tissue compared to that in benign prostate hyperplasia tissue. Int. Neurol. J. 20, 122-130. https://doi.org/10.5213/inj.1632552.276 